This is a post-print accepted manuscript published in

Global Discourse

Please cite this publication as follows:

Hanna-Mari Ikonen: Precarious Work, Entrepreneurial Mindset and Sense of Place: Female Strategies in Insecure Labour Markets. Global Discourse 3(3-4): 468-481. DOI: 10.1080/23269995.2013.864085

You can download the published version at:

http://dx.doi.org/10.1080/23269995.2013.864085 or http://www.tandfonline.com/eprint/TwmWIKVGJyiu4XiJeHbP/full\#.UsGHo7Tfm2k

\title{
Precarious Work, Entrepreneurial Mindset and Sense of Place: Female Strategies in Insecure Labour Markets
}

\author{
Hanna-Mari Ikonen D.Sc.(Admin.) \\ School of Social Sciences and Humanities, University of Tampere, Tampere, Finland \\ Kalevantie 5 \\ FI-33014 University of Tampere \\ Tampere, Finland \\ Tel: +358 503186097 \\ hanna-mari.ikonen@uta.fi
}




\section{Precarious Work, Entrepreneurial Mindset and Sense of Place: Female Strategies in Insecure Labour Markets}

This article participates in the discussion on the uncertainty of working life by providing a viewpoint of one individual's experience of it. The article argues that entrepreneurship and employment are forms of income that are not separate from each other; instead, in precarious labour markets, individuals can alternate between the two. An entrepreneurial mindset and practices are required from the self-employed and employees alike, but neither form of livelihood ensures a permanent income. Though in different ways, the process of precariatisation touches many groups of people, and the varying alternatives for navigating this situation are deconstructed here. The analysis discusses how surviving precarious labour markets and uncertain income requires a lot of endurance and self-governance as illustrated by an in-depth interview with a woman who lives in a remote area. The analysis also proves that the opportunity to remain in a place of residence and establish a sense of belonging has a significant impact on an individual's ability to experience everyday pleasure and permanence, especially when everything else around them is changing in ways over which they have little control.

Keywords: entrepreneurship; precarious work; sense of place; rural areas; gender

\section{Introduction}

Unpredictability and inconstancy are characteristic of contemporary labour markets. This precarious situation affects not only work but other areas of life as well. As old institutions are losing their ability to provide stability, reliability and predictability, and as companies outsource their operations and agency work increases, individuals are left to their own devices. In such situations, everyone is supposed to assume an entrepreneurial attitude and take care of their employability themselves. One way out is to create their own work as entrepreneurs. Entrepreneurship is not, however, a simple or a permanent solution for employment, as is demonstrated in this article.

Another alternative for finding work in a world of changing work trajectories is relocation. However, migration is not an option for everybody; in fact staying put may be 
an important way of tolerating uncertainty. Therefore, this article explores the question of 'placeness.' Based on previous studies, it is evident that a sense of place influences the choices people make; a place is a limitation but it also provides resources, emotional or other (Eyles 1985; Heikkilä 2011; Ikonen 2008, 2012; McDowell 1999; Relph 1986; Tolonen 2005; Tuan 1977; Varis 2005). However, the emotionally laden meaning of place has not been significantly addressed in studies on employment and precarity. Actually, placeness and settling down have been seen as opposite conditions to an ideal figure of the current spirit of capitalism (Boltanski and Chiapello 2007). In addition to the concept of a sense of place, I work with the concept of an entrepreneurial mindset, which, in turn, is deduced from critical discussions on working life research that highlights individuality, potentiality, agility, flexibility and readiness to steer employment more than industriousness, loyalty and formal qualifications (Adkins 2008; Adkins and Jokinen 2008; Atkinson 2010; Boltanski and Chiapello 2007; du Gay 1996; Jokinen et al. 2011; Mäkinen 2012; Ross 2009; Standing 2011; Veijola and Jokinen 2008; Vähämäki 2009). Neo-liberal time takes various forms. For example, Will Atkinson (2010) points out that even though de-standardization of careers and several job shifts really have taken place, they are remarkably driven along class tracks. In Atkinson's study on worker reflexivity, those who were 'dominant,' i.e., had economic and cultural capital, were more capable of perceiving their changed work trajectories as an opportunity to downshift for a while, start something totally new or concentrate on something they had always wanted to do. Even the 'dominated' told about negotiating and taking active decisions - since they were familiar with the reflexivity discourse - but social mobility was scarce as the class-related material pressures hindered their options (Ibid.). 
Insecurity, precarity and in-work poverty are also examined by Jeremy Morris (2012), who studies how Russian male industrial workers see permanent, 'normative' employment as insecure. In a post-Soviet Russian context, a lack of control over work processes and over-emphasized self-regulation make the work feel precarious, while compensatory social assets can be found in blue-collar networks of solidarity. These networks provide class-rooted alternatives to wage labour, such as opportunities for entrepreneurialism in the lay sense of the term, other informal jobs and, importantly, a shared feeling of self-dignity. However, the social capital of these networks remains marginal, which indicates the salience of class in debates about precarity (Ibid.).

Equipped with these notions on the new economy, I focus on the porous line between wage work and entrepreneurship, as well as on variety in entrepreneurship, which I think needs deconstruction. Even in the contemporary era of selfentrepreneurialism, emphasis must be put on class position, gender and geographical place, as these aspects, among many others, affect self-employment - or lack of it. My case study in particular is intended to add to the discussion about the interface between place and entrepreneurship in precarious times. In this article, I address the question of what it's like to inhabit the no-man's land between employment and entrepreneurship in a specific spatial context and illustrate it using a tangible interview example. I seek strategies for concretely managing and mentally tolerating the uncertainty of this paradoxical situation and provide an understanding of the social and spatial context behind those strategies. The empirical data for this article consists of one interview, which is part of a more extensive collection that includes a survey and interviews regarding the work and everyday life of female entrepreneurs in rural areas in Finland 
(Ikonen 2008; 2012). This particular interview gives a voice to a divorced mother of two children, who lives in a remote rural area and balances between being an entrepreneurial cobbler and working part-time in shoe sales. Of course, there is not one definitive experience of the precarious worker and people have different capabilities to manage uncertainty. It is also difficult to predict the movements of neoliberal labour markets and globally affected local economies. Therefore, the analysis shows common phenomena in work and the economy in a context.

The article continues by reviewing the entrepreneurial ethos with the core idea that entrepreneurship is not separate from employment or other kinds of livelihoods. The concept of an entrepreneurial mindset describes their more and more common junctions. One objective is to open the discussion on the connections between entrepreneurship and employment in the rapidly changing demands of working life. Then, the emotionally laden sense of 'placeness' and the regional context of a remote area in Finland are discussed. Thereafter I introduce the interview data. When analysing it, I discuss the paradoxical means of controlling the uncertainty of work, and expand upon the significance that place of residence has in the uncertain situation. Finally, I conclude with a number of uncertainties and ways of managing them in the state of being between wage work and entrepreneurship, and look at opportunities and threats from a wider working life perspective.

\section{Demand for an entrepreneurial mindset and the precarious entrepreneur}

Regarding contemporary working life, the article makes two claims: (1) maintaining a strict divide between wage-work and entrepreneurship prevents us from seeing the reality of working life, and (2) supposing entrepreneurs to be a certain kind of group and not 
deconstructing that group prevents us from seeing the real accomplishments of entrepreneurial activities. Therefore, we begin by trying to understand the societal contexts for the entrepreneurial mindset and the gnawing insecurity that comes with it.

The ideological push towards entrepreneurialism has been going on for quite some time. The demands for assuming an entrepreneurial mindset come from the ideology of neoliberalism, or the related concepts of advanced liberalism, turbo capitalism, knowing capitalism and the new spirit of capitalism (on the grouping of these terms, see du Gay and Morgan 2013, 2). The rationalities these modes of capitalism provide have taken a hold of governments, institutions and organisations which now echo the salience of entrepreneurship, marketisation and choice (Ibid.). For example, Tony Watson (2009) states that neoliberal arguments about an entrepreneurial culture permeated the United Kingdom in the 1990s, when it became widely accepted that entrepreneurial values as such were important and that they made attaining added value and speeding up economic growth possible (also du Gay 1996; Obgor 2000). Even in Finland, entrepreneurialism is widely seen as the saviour of the post-capitalist country as an unavoidable development when the state cannot or does not want to look after its citizens' welfare as it used to under free global competition. Entrepreneurial rhetoric has even found its way into tangible political measures.

There seems to be no end in sight for the pervasive spirit of entrepreneurialism. Citizens are encouraged to be active and take responsibility. For example, there is pervasive use of the term 'lifelong learning,' which refers to a self-reflexive and proactive attitude that should empower a person in the neoliberal labour market (but there is little discussion of how this is actually not equally accessible or beneficial to everybody, see 
Atkinson 2010). The demands are not necessarily put forth directly; instead people internalise control, responsibility and internal entrepreneurship without their autonomy being formally interfered with (Miller and Rose 2008). Other researchers have talked about these elements in terms of enterprising self (Rose 1992) and self-subordination (Vähämäki 2009).1 Individuals are given responsibility for issues and changes they can hardly influence. In this context, the need to tolerate and manage uncertainty applies to virtually all forms of work, even though it is traditionally more familiar to small business owners.

This leads to the entire working life and all forms of work becoming imbued with the ideology of entrepreneurialism, which, however, proves to be very special and exclusive. Hans Pongratz and Günter Voss (2003) use the term 'employee-entrepreneur' or entreployee (in German Arbeitskraftunternehmer) to describe the employee who manages himself or herself in an entrepreneurial manner. The employee takes responsibility for matters that used to be the employer's obligation. He or she manages his or her working time, the contents and quality of his or her work and networks, independent of time and place. Nevertheless, these requirements and practices do not directly lead to the independence traditionally associated with entrepreneurship: the company's profit objectives ultimately set the conditions.

Undoubtedly, there are positive sides to the formation of the character of an entreployee, such as changing from a passive worker into an actor who creates

1In Finland, entrepreneurship education is even incorporated into the school system from primary schools to universities (Komulainen et al. 2011). Still, the advocates of entrepreneurialism are criticising schools for poor results of entrepreneurial education. At any rate, both the supporters and the critics of entrepreneurialism understand that even by educating people to have an entrepreneurial attitude, it is impossible to control the operations of an economy that has broken loose from the old management logic. Critics conclude that citizens are meant to learn that they cannot rely on public systems, which means that they also learn to manage themselves and to rely only on themselves. 
opportunities for himself or herself and who can utilise these acquired skills when working for other employers. An individual who can commercialise and market his or her skills can take advantage of the new labour markets. (Ibid, 6-8). The problem is that these skills and jobs are only available to a limited group of people with certain classed capital, and similar efforts do not create the same results for everyone (Peltokoski 2012; Standing 2011).

Neither entrepreneurship nor an entrepreneurial attitude as such are totally alien to the working classes, less privileged or dominated (whichever term we use). Quite the opposite, in fact: for Finnish rural yeoman, for instance, making a living has required the adoption of a hard-working, opportunistic attitude, and craftspeople have independently controlled their work processes from beginning to end as well. What is new is that more and more individuals end up as entrepreneurs suddenly, involuntarily, temporarily and due to a lack of other possibilities. Accordingly, people in various situations with various backgrounds may find themselves as entrepreneurs. That is why 'groups of precarious workers, consisting of many subjectivities, precarious people, offer a more comprehensive repertoire of lives than the currently available majority group's models, such as employee/entrepreneur/student' (Meriläinen 2011, 160). Both the lowest end of the service economy (where people carry out routine tasks) and the highest end (which includes the creative classes of the knowledge-intensive economy) may meet with the radical uncertainty about the future, transience of employment contracts and uncertainty regarding social security benefits. Because of their different background capitals, they are differently equipped to treat their changed trajectories (Atkinson 2010), but the system of capitalist exploitation touches them all. Nevertheless, precariousness is especially a threat 
on the lower levels of the labour division hierarchy, where flexibility of working life means discontinuous incomes and poverty (Peltokoski 2012, 98).

Fixed-term employment and changing work trajectories do not necessarily lead to precarity and a feeling of uncertainty. Likewise, being precarious does not automatically lead to becoming an entrepreneur. However, for some, when the only predictable things are uncertainty and change, the wish to manage one's own life leads to viewing selfemployment as an attractive option (Ross 2009, 6). Yet, self-employed people have rarely been seen to have something in common with precarious workers, which means that their experiences have largely been overlooked when studying uncertainty and temporariness. At least in Finland, the institutionalised working life research has so far focussed on normative employment and given less attention to the emerging issues in the working life. Therefore it is time to have a look at the differentiated processes, practices and motives of entrepreneurship.

In relation to class, this article defines entrepreneurship as a socially stratified category which has to be deconstructed, in contrast to its automatic social construction as middle-class.2 Nowadays, the entrepreneurial status does not dictate the entrepreneur's social class, which would include economic opportunities, education, tastes and consumption behaviour. The status of entrepreneurship changes in a precarious world where everyone should possess an entrepreneurial attitude, and when people become entrepreneurs as a result of outsourcing and being encouraged to become freelancers.

${ }_{2}$ Even official statistics treat entrepreneurs' social statuses as too homogenous. Statistics Finland only divides workers into employees and entrepreneurs, even though the group of entrepreneurs is highly heterogeneous and people can alternate between the two statuses or even hold both simultaneously. Almost half of all entrepreneurs are self-employed, meaning that they do not employ others. Their number has increased dramatically and many have a low level of income and high level of poverty (Palkkatyöläinen 2011). In the contemporary world of work, entrepreneurs also include disadvantaged people, particularly women. 
Thus, the backgrounds, tastes and other indicators of social class become even more mixed among the category of entrepreneurs.

\section{Connecting a sense of place and a remote place}

Research often overlooks the characteristics of local labour markets, not to mention the fact that people do not always look for work in large cities, even though they may be willing to commute dozens of kilometres in their local area. Job opportunities and requirements set for employees are, in other words, coloured by the place in which they live (McDowell 2009; Tolonen 2005; Varis 2005). How does a place shape the range of jobs and an individual's choices then? Theoretically, according to Doreen Massey (1994), for example, places are constellations of certain physical characteristics, history, economy and culture and are therefore all different. However, places are not closed entities and do not have endogenous, essential identity but places are unique exactly because of mutual relations with other places. A global economy and its logics build places. There is inequality in how suitable and attractive a particular place is seen for economic activity, and inequality in terms of various indicators of social well-being (Ibid., 50-51). Different social groups and individuals are positioned in very distinct ways in relation to flows of capitalist production: some people initiate movement, others are more imprisoned by it (see Skeggs 1997; 2004 about the necessity of staying put and how it is connected to class in her argumentation). Thus, categories such as class, gender and ethnicity define a person's experience of a place, but in a very complicated way.

The feelings of insecurity and unsettledness in the middle of a hastened capitalist flux can lead individuals to resist changes to the peace and quiet of a certain locality that provides them with a strong sense of place. Massey $(1994,146-173)$ warns against 
seeing places as romantised and static (and maintained as such by women's labour) as it sometimes has been seen. However, I argue here that being strongly connected to a place can be empowering. In accordance with what Massey ponders, I suggest that people's feelings about a place are a result of direct or indirect interacting with other people who see that place in a different way. Similarly, in interaction with other places - bigger, far away or in other ways different - one can attain an enhanced feeling of placeness. Empowered by this extroverted, conscious sense of place, one is equipped to meet unavoidable changes and can successfully respond to rather than deny them.

To come closer to the material context of this study on work and entrepreneurship in a place, it is worth noting that regional development acts in Finland rest largely on the hope of entrepreneurship. When structural problems of remote areas (such as the decrease of agriculture and basic industry and demographic changes towards the majority of elderly people) have continued for a long time and governmental safety nets have been loosened, the remaining people of working age (as well as potential new residents) are encouraged to acquire a livelihood as entrepreneurs.3 Ideally, an individual's sense of place and regional development acts are in harmony; in any case both ways of imagining the place exist simultaneously.

3Rural policy starts with farms having to be able to reform themselves, thus linking entrepreneurship to them, and developing entrepreneurship completely independent of farming. One-third of farms do in fact practise business outside farming, usually machine contracting. New business and income opportunities are seen, for example, in care and other service industries and alternative energy generation. Adding value to foodstuffs and tourism are also potential industries. Women who live in rural areas generally find employment in the same industries as they do in towns and cities (Rural Development Programme 2007). The number of women entrepreneurs is high in the entire country: farming excluded, one-third of all entrepreneurs are women (in total 79,400 female entrepreneurs, the highest figure in the EU) (TEM 2010, 18). Despite the high number of women entrepreneurs, the Finnish Government has set the objective of increasing this share to 40 percent (Ibid, 26). Increasing the share is seen to be important for national competitiveness amidst global capitalism, tapping into women's workforce resources, and retaining a balanced demographic structure. The Government believes that promoting entrepreneurship among women improves the employment rate and equality between genders and regions and thus helps remote places become attractive locations for economic activity. 


\section{Data and method}

Entrepreneurs and employees are often studied at only one moment in time, which can make the respondent's entrepreneurship or employment seem more stable than it actually is. The respondent interviewed for this article was followed over a longer period of time. The analysis is initially based on the interview conducted in 2009. In addition, the thoughts expressed by the same respondent in a previous interview seven years earlier provide a backdrop for the analysis. The interview is further complemented by data from a survey that targeted 132 women entrepreneurs who work in the rural Northern Karelia and Tampere regions of Finland. Of this data, 18 interviews with women entrepreneurs were selected to provide a background for this article. Also included are the data from later follow-up interviews with the same women (with the exception of two who could not be contacted). Based on these previous survey data and interviews, I was aware of the respondents' backgrounds, life situations, ideas concerning their place of residence and experiences as entrepreneurs. The follow-up interviews focused on updating the information and discussing the overall changes. The interviews covered three wider themes applied to each respondent's situation at the time of the interview: the women's work situation and whether it was entrepreneurship or another activity; their relationship with their place of residence and the practices related to this; and questions pertaining to gender, for example, the significance of gender in work-related practices and a family's internal way of working.

The woman who was selected as the subject of this article is an example of the uncertainty of the times and of individual careers, and of how individuals try to manage the uncertainties and what potential futures they hope to gain for themselves. Her first 
interview provided a background; with this interview I show how employment is not permanent. The respondent shares the situation of the other interviewed women entrepreneurs, in that she has made work-related decisions and choices based on what is possible in her place of residence and what she considers to be the best for her family. Some other respondents, too, are living between entrepreneurship and other forms of earning a living.

I review the entrepreneur's interview specifically from the perspective of experiencing change, its impacts and management. Experience and management of one's own life path and setting its past, present and future in a societal narrative context can be viewed with narrativity (e.g. Herman 2009). Catherine Kohler Riessman (2001) summarises that narratives construct people's identity, make experiences comprehensible and illuminate the intersection of biography, history, and society. At the same time, the narrative and the narrator are born again (and again) when the story is told. According to Paul Ricoeur (1991), narratives weave together heterogeneous elements in a story and individual stories into wider social narratives. Therefore, the narrative analysis method is suited for an interview that evaluates one's own present state in relation to the past and future working life. My interviews did not essentially aim to tell stories; the narrative is only a method of thinking that steers the analysis. I draw attention to what the respondent chooses to say about her situation and how she understands her opportunities and herself as an actor. Nevertheless, in this article I focus only on certain themes and not much on the way the narrative is expressed. Steered by my research questions, I highlight the theme of work-related uncertainty. 


\section{In the cobbler's shoes}

The 45-year-old female respondent used to run a cobbler's shop. The business is currently on a hiatus and she works part-time elsewhere. The reason for the pause in business is that she was taken ill due to physical exhaustion caused by the intensive pace of work, which finally manifested itself as physical pain in the hands and made her unable to work. She divorced a few years ago. One of her children has moved out and is studying elsewhere, and the other one still lives at home and attends comprehensive school. She has not considered and does not want to consider moving away from the area, even though suitable jobs are hard to find where she currently lives. The family home is very important to her: it was built by her grandfather and she grew up in it. Today, and in the near future, she wants her children to have a place to which they always feel they can return. In the future, the children may be able to use the house as their home or as a summer cottage, and it may also be possible to work from there again as an entrepreneur.

Since putting her business operations on hold, the respondent has worked in various positions in the service industry, including in a grill café and as a cook at a service station. At the time of the interview, she was employed part-time in a shoe shop. The respondent has made tentative plans to start the business again by making leather products and selling them during the Christmas season. If this were to happen, she would have to put strict limits on her work by not necessarily accepting all orders and not imposing too strict of deadlines on herself. She enjoyed all elements of working as a cobbler and managing the overall operations independently, but wished the bigger picture had been more controllable. Getting supplies, designing the products, handling customer service and making the products all fit into a normal working day and generated enough 
income, but combining the running of the business in all its elements with life's other demands was difficult. This is often an issue for female entrepreneurs in particular.

\section{Culmination of uncertainty and the struggle of control}

Leaving entrepreneurship behind, moving to a new situation, evaluating the consequences of these actions and contemplating the future dominate the follow-up interview. The move away from entrepreneurship was not a carefully considered, final and fully satisfactory decision. This is what the respondent says about her current situation and how she found herself in it:

R: Well it [pausing the business] happened because I got this sudden illness first, and they thought it was something caused by work stress. Then they took some more tests and it wasn't that after all. And then I got the long sick leave. And then, to give it a go, I tried shoe repairs, and it just didn't work anymore, my body couldn't take it anymore, full-time. Q: Yes.

R: So then I started applying for other jobs and that's the road I'm still on. So I still have it [the business], because I didn't want to close it down completely or put it away, perhaps one day I can still get back to it or at least work somewhere else part-time and then on my own part-time. To make a full day of it.

Q: Yes. Where do you work now?

R: Well now I work at the shoe shop.

Intensive schedules and long days already emerged as themes in the first interview; at the time the respondent did not talk about them as her own negative 
experiences but mentioned comments from other people. The respondent says that her current situation is temporary, although she does not know how long it will last and in what format she can put her plans into action in the future. She evaluates her options spontaneously. The words 'being on that road still' describe the temporariness, sense of being side-tracked and the idea that in some sense she is expecting to arrive. She has taken short-term jobs in the immediate past and will perhaps do so in the near future, but 'now' her job is to be a sales assistant in a shoe shop. Her thoughts and identity are still those of a cobbler entrepreneur's, because that was work she enjoyed. She cannot stay in the present, because her current job is temporary. It is this very precariousness that leads to the compulsion of forecasting the future, but as unpredictability is inherent in the future, the situation is fragile and continuously prone to unexpected changes. Tolerating uncertainty and planning the future must take place concurrently.

In the following excerpt, the respondent assesses what it's like to be an employee as opposed to an entrepreneur:

R: Otherwise I really like it: all the stress that comes with your own business is gone, working the long hours and never being able to take any time off or anything, so this is luxury now. But being part-time, financially and economically it's a complete disaster ... But then mentally and otherwise, it's good, and you notice that the professional ... the knowhow is really good there too.

She thinks it is positive that she is able to utilise her previously acquired skills in the current job (cf. Standing 2011, 121-124). Being able to hold on to her professional identity gives her a feeling of control and of having previously achieved something 
important, even though the emphasis on the current job's easiness hints at underused capacity. The current situation highlights the fact that the part-time sales assistant does not earn enough money. As a crafts entrepreneur, she had a low income but there was still the opportunity to generate more income through the business. In a labour-intensive field, this meant long and stressful days, which weighed heavily on her health and were compounded by all of the other non-work related responsibilities of everyday life. Questions pertaining to economic opportunities limit her choices and the available options. As setting up the cobbler business was a solution to the challenges of trying to balance difficult work hours with childcare, it seems that she has gone from one paradox to another, and it does not seem that there are many means with which to manage the situation. Even though she is an active agent in her own life, as called for by the demands of the current labour market, being able to achieve this requires her to continuously find a balance between a living wage, well-being and the limits of endurance.

\section{The paradox of easy work}

When asked whether the respondent would prefer entrepreneurship or employment in an ideal situation, she explains what would be her terms for choosing entrepreneurship. It is interesting to note the type of employment against which she compares entrepreneurship. A job that is realistic would be working-class employment that requires relatively few skills, is poorly paid and not very challenging (cf. Atkinson 2010; Peltokoski 2012, 98). It is easy compared to middle-class jobs that are knowledge-intensive and permeate across time and place, and it is also easy compared to self-employment. Considering the respondent's background, her current employment is unusually independent (cf. Morris 2012). The supervision is not continuous and visible. This can make even a job that is too 
easy more likeable. There are also limits to the job's independence and entrepreneurialism, which means that she is not expected to perform tasks that create feelings of inadequacy and uncontrollability (as more demanding employment or entrepreneurship could do).

Q: [...] if you could choose completely freely, in an ideal situation, would you rather be self-employed or work for someone else?

R: I'd be self-employed, run the cobbler's shop, no doubt about it. Yes I would. I mean if I knew that I could do it in the eight hours, to make it work, the system, and it would bring in enough money to live on without having to worry all the time about whether there will be enough money and also the clients would really come and get their stuff and pay for them on time. So yes, absolutely, I would choose it. Yes.

Q: Yes.

R: But this is easy now, I've seen both sides, working for someone else, I've done that my whole life, and then had my own shop and my husband has always had his own business. I've seen the ups and the downs, the good and the bad, everything. So, well, it's so easy to work for someone else, you just take care of your own hours and do your job well and get to have your holiday. It's so easy. It's easy in that sense. But then running your own business, it's the independence, that's my thing. But that's why I like working in the shoe shop, because my employer and the shoe factory are in the [neighbouring town], they have another shop there, and I take care of this one on my own and work the sales alone. So I am independent 
here, too. So in that sense to me being able to work independently is also a good form of being sort of an entrepreneur.

Independence is on the one hand an absolute requirement - employees should work like an entreployee who is responsible for his or her self, own work and employment - and on the other hand a distant dream: do they trust me enough to let me do things my way? Even apparent independence is not always allowed. Linda McDowell (2009) states that people in the growing area of service work, home care and nursing are lacking missing the daily, immediate supervision. It is the very independence of work that motivates the employees, because a lack of strict control is not usual in lower income working-class jobs. Independence is, of course, to some extent illusory; even a shoe shop has to be run according to executive orders.

What is thought to be a temporary and easy part-time job enables a more versatile everyday life than being self-employed and trying to continuously scrape together a living. On the one hand, she puts herself in the intentional, middle-class downshifter's position where people slow down and withdraw from career competition (e.g., Chhetri, Stimson, and Western 2009; Ikonen 2010). On the other hand, she speaks with an apologetic tone because the phase with the easy job is thought to be abnormal. She is always ready to take on more demanding work as soon as she feels well enough. In reality, her days are filled with things to do, and she admits to being afraid of being stuck. In the background is the concern over job fitness; she says she knows people who no longer want to go to work after not having to do it every morning. The respondent thinks it is self-evident that she has to take responsibility for always being employable. I interpret this as entailing an internalised concept of an ideal Finnish citizen, worker and 
rural resident, and an industrious, self-sacrificing woman and middle-class ideal of femininity in the vein of Beverly Skeggs (2004), against which the working-class woman is compared. Striving towards a middle-class ideal transforms into a form of internalised control (Lahikainen and Mäkinen 2012).

\section{The paradox of loyalty}

The interview involves lots of orientation towards the future because the current situation is known to be temporary. When talking about her tangible plans for the future, the respondent uses rhetoric that emphasises loyalty.

Q: What are your plans now?

R: Well if they ask me to work more in the autumn, then of course I'll do it because I've promised I would.

She intends to help during the summer holiday season and afterwards in the shoe shop, even though actual contracts have not been made. The employee is loyal to the employer. This attitude is at odds with the flexible knowledge workers' orientation towards individual careers due to organisations treating them as disposable workers (Gherardi \& Murgia 2012) but which is also contrary to the working-class rebel against employers who do not any more provide reliability they used to (Morris 2012). The interviewee's speech takes the perspective of a loyal helper: she has even recently been substituting for other employees in the job she had prior to working in the shoe shop, so that the other employees 'could take their holidays.' Even when the business was on a hiatus and she was working in other jobs, she still expressed kindness and kept promises: she supervised a man's traineeship in her shop so that 'we [sic] were able to finish his course properly.' 
To some degree, being loyal is worthwhile to her because in her insecure but easy wage work, there is the opportunity to separate work and leisure. Of course, her loyalty does not guarantee reciprocal loyalty. It is typical of women to be flexible, adjustable and go the extra mile for their clients. Loyalty and thinking of others can lead to small work opportunities that can help with income, but they can become a drain and prevent one from taking significant steps to improving one's own situation.

The interviewee recognised her own entrepreneurial style even in the first interview conducted at the beginning of the 2000s. I called the narrative about it an interpretation repertoire of doing well, which included being committed and trustworthy (Ikonen 2008). At the time she was motivated by her enthusiasm, new skills and emerging professional pride and thought that she could make it without taking any time off. Later the job turned into a struggle in terms of keeping up with deadlines she had loyally promised, coping and making a living. Now she recognises with more clarity where she went wrong. She should have created time and space for herself, closed to the customers, not been so hard on herself and not so proud of being able to serve everyone. One should not give everything of oneself because thorough craftsmanship is no longer rewarded, as is deduced for example by Sennett (2006) and Vähämäki (2009). Maintaining boundaries, rather than overlapping functions, could be the key to job fitness (Jokinen 2010, 50).

\section{Permanence provided by place in the midst of uncertainty}

Characteristics of place (restrictions, an outsider could say) combined with her family situation, influenced the decision to set up a business. The entrepreneur trained herself, changed careers and became an entrepreneur in order to be able to take care of her 
children with more flexibility than when taking them to two different day-care centres at times dictated to her and set in advance. There are limited day-care facilities within a convenient distance in rural areas if your working hours are different from normal office hours. This made the respondent's whole life seem like one big childminding arrangement. She also hoped to be able to take care of the maintenance work and repairs required for the terraced house. These were her responsibilities even before the divorce because her husband spent weekdays away. Now the situation has changed in terms of her 'charges,' but she still signifies the combination of working part-time and being a mother in a positive way. She was unable to control her working pace as an entrepreneur, now that she is an employee she has more time for the children. She also has more time to dedicate to the repairs and maintenance of the old house than she did when working from home. Place and motherhood go hand-in-hand throughout the interview and quite evidently throughout the years: both affect the practices of entrepreneurship.

Both the first and the second interview reveal that work is subordinate to remaining in her place of residence. Staying put is not interpreted in any way as being forced.4 The will to stay in the place of residence has also been noted in the interviews conducted for the project on casualization and precariousness in Northern Karelia. In them, the respondents even feel guilty for not being willing to relocate to southern Finland (Heikkilä 2011, 45). They worry about being active enough because they are unwilling to leave, but at the same time they feel that place gives them a sense of permanence that work does not provide. Staying put is often a question of necessity,

4Staying is an objective and a desired state of affairs as seen throughout the data collected for this article (see Ikonen 2008; 2012). An indicator of the will to stay is the fact that of the 16 interviewees (with the exception of one), all lived in the same rural municipality at the time of the follow-up interviews. The only respondent who had moved to the nearby town had done so because she had to and did not feel at home in her new place of residence. 
claims Skeggs (1997, 2004), among others: those with the best incomes can leave and move around, whereas the working classes must stay put. In the Finnish rural context, combined with gender aspects, this holds true. For rural men in particular, staying put is connected with a misery of sorts, especially for an unmarried adult male who lives with his parents. Statistics prove that men stay and women leave (Rural Development Programme 2007, 5), and men in remote areas have fewer qualifications and less social mobility than women who move (in Ireland: NíLaoire 2001). In contrast, from a global perspective, in order to avoid becoming disadvantaged some people are forced to leave their homes and move, for example by seeking work in cities or abroad (such as Estonian construction workers in Finland). Thus, place and spatiality are indirect ways of talking about social classes: where we are from, where we live and whether we leave or stay define us (Keith and Pile 1993; Tolonen 2005).

The cobbler does not want to be among those who leave. She has wanted to stay in her home 'ever since she was small,' and there is 'no way she is leaving.' Emotional attachment to place is a human emotion for which there is not necessarily a rational explanation, except that 'it must be something in the water' (Eyles 1985, 126). Edward Relph (1986) writes about an authentic attitude to place. He divides this attitude into a conscious and unconscious sense of place. The unconscious feeling of being inside and belonging is widely present in my interviews. For example, the cobbler talks about place as 'her own little world' and uses this metaphor to make a distinction from the world outside where her entrepreneur husband worked. She talks about the husband being out and about several times by saying, for example, that her 'husband works in the outside 
world all week.' She voluntarily limits her 'own world' to the size of her house: an area that is emotionally significant.

An explanation of the significance of place can be sought from the perspective of assets and resources: the respondent describes her choice to stay put as a resource. She has been able to, not forced to, stay in her childhood home and still be an active agent in her life as a worker and a mother. She can take care of the house on her own. Her own house is an achievement, which she wishes to underline perhaps as a sign of being proper and respectable (Skeggs 1997) because 'a family in the little cottage is not a problem family' according to Finnish housing rhetoric (Uimonen 2008, 128). The house is also a tangible resource because it has previously offered, and perhaps will offer again, the premises for practising a livelihood.

\section{Conclusions and discussion: Network of uncertainties and control}

Uncertainty in the respondent in the state of 'in-betweenness' is caused by the paradox that there is either too much work (when self-employed) or too little work (as an employee at the shoe shop) to ensure a sufficient livelihood, because work is available in short, temporary patches. If she were to continue as an entrepreneur, she would have to think about how to prevent the entrepreneurship from depleting her strength and health. It is possible that she now knows her limits better and does not slavishly follow requirements set by others or by her for herself. This skill could give a sense of being in control in uncertainty. Likewise, the respondent valuing her professional skills and liking her job generates a feeling of being in control. The wage work is also easy because at the end of the day you can leave it behind. Control strategies include the knowledge of being able to live alone in the beloved house. 
The former cobbler sees potential to improve her income and sustain survival strategies in that the children are about to leave the nest (which can give her the strength to re-launch entrepreneurship), and because the extension of employment has been promised for the summer holidays. It is possible that she will work in one short, temporary job after another, which to the respondent is a better alternative than having no work at all. She is loyal to accepting the short, temporary contracts in a flexible manner. On the one hand, she refuses to see the challenges caused by the place and local economy, but on the other hand she does not have to, since there seems to be enough work as a cobbler. It is nevertheless possible that the remote area where she lives will fall further into economic decline, in which case there would be fewer employment opportunities available. The demand for Finnish-made shoes may further decline and people may need or want fewer repairs in a disposable culture. Therefore, considering the respondent's work and education history, the outlook for employment or entrepreneurship opportunities may not, after all, be very good, and the process of precariatisation may continue.

Illustrated by the respondent's narration, I have tried to give a shape to the changes in the labour markets, local economies and personal valuations that have a critical effect on the living options available to and chosen by individuals. The same problems and attempts at control can be widely perceived in working life as the process of precariatisation touches several groups of people. Still, the precariat is yet a class-inthe-making (Standing 2011, 7), sharing some characteristics of other classes and not yet a distinctive socio-economic group. Exactly this lack of group identity is an obstacle for controlled change on a wider scale because only a larger group of people, the crowd, 
could generate a change away from fordist society's practices and vocabulary (which no longer reflect the working life) (Jakonen, Peltokoski, and Virtanen 2006, 8-9; Peltokoski 2012; Standing 2011). As an indication of the lacking group identity, the former cobbler does not bring her uncertain work situation into the political agenda. She does not have a forum in her life where she could see the experience of precarious work to be a shared one - instead the suffering is construed as an individual problem (Skeggs 2004, 59). The solutions are to be found individually.

As a result of the entrepreneurial mindset demonstrated both in employment and entrepreneurship, the respondent has also experienced the negative consequences of excessive dedication: the time pressures and the stress. As young employees who work in glamorous fields that require specialised skills are the ones who can benefit the most from the entreployee attitude, this former cobbler is mainly a part of the less successful but ever-growing group of people for whose work there is mainly short-term use without guarantees of the future (Pongratz and Voss 2003, 12-14; also Atkinson 2010). Because incomes are low - or, correspondingly, there is too much work to do - in this sense she reminds us of the working poor (Ehrenreich 2001; McDowell 2009; Standing 2011). These people do not make a sufficient living, even though they are active and have skills and education, because they cannot get the jobs that pay well enough or because there are long gaps between their contracts. They live mainly in large cities where the cost of living is high, but even in remote areas, when the jobs from industry, farming and the public sector are cut, the amount of income generated from practising a business, parttime jobs or social benefits remains so low that it provides a limited existence. The cost of living can be low in remote areas, but moving about is expensive because it takes time 
and money to travel in search of the disappearing services and jobs. Many choose to move away, even though in expensive cities can only access living conditions that they feel are inferior. The respondent, however, is one of those who, even rebelliously, want to retain one constant in her life when work or family are no longer a guarantee of permanence: her place of residence. Staying put place of residence feels like a voluntary choice, thus bringing a sense of well-being and faith in the future, which helps to tolerate the scarcity and uncertainty caused by working conditions.

\section{Acknowledgements}

The writing of this article has been enabled by funding from the Academy of Finland, decision number 232213. I am grateful for the referee comments to the earlier version of this article.

\section{Notes on contributor}

Hanna-Mari Ikonen is a post-doctoral researcher at the School of Social Sciences and Humanities, University of Tampere, Finland. She has published on women's entrepreneurship, gender and sexuality in media representations, and downshifting, all in the context of rurality. 



\section{References}

Adkins, L. 2008. "From Retroactivation to Futurity: The End of the Sexual Contract?" NORA (16) 3: 182-201.

Adkins, L., and E. Jokinen. 2008. "Introduction: Gender, Living and Labour in the Fourth Shift." NORA (16) 3: 138-149.

Atkinson, W. 2010. "The Myth of the Reflexive Worker: Class and Work Histories in Neo-Liberal Times.” Work, Employment \& Society (24) 3: 413-429.

Boltanski, L., and E. Chiapello. 2007. The New Spirit of Capitalism. London: Verso.

Chhetri, P., R. Stimson, and J. Western. 2009. "Understanding the Downshifting Phenomenon: A Case of South East Queensland, Australia." Australian Journal of Social Issues 44 (4): 345-362.

Ehrenreich, B. 2001. Nickel and Dimed: On (Not) Getting By in America. New York: Metropolitan Books.

Eyles, J. 1985. Senses of Place. Wellingborough: Silverbook Press.

du Gay, P. 1996. Consumption and Identity at Work. London: Sage.

du Gay, P., and G. Morgan. 2013. "Understanding Capitalism: Crises, Legitimacy, and Change Through the Prism of The New Spirit of Capitalism". In New Spirits of Capitalism?: Crisis, Justifications, and Dynamics, edited by P. du Gay, and G. Morgan, 1-42 . Oxford: Oxford University Press. 
Gherardi, S., and A. Murgia. 2012. "By Hook or By Crook: Flexible Workers between Exploration and Exploitation." Research in the Sociology of Organizations 37: $75-103$.

Heikkilä, K. 2011. “Jäädä vai lähteä?” In ”Yrittäkää edes!” Prekarisaatio PohjoisKarjalassa, edited by E. Jokinen, J. Könönen, J. Venäläinen, and J. Vähämäki, 37-50. Helsinki: Tutkijaliitto.

Herman, D. 2009. Basic Elements of Narrative. Malden: Wiley-Blackwell.

Ikonen, H-M. 2008. Maaseudun naiset yrittäjinä. Elettyjä käytäntöjä ja jaettuja merkityksiä yrittävässä yhteiskunnassa. Tampere: Tampere University Press.

Ikonen, H-M. 2010. ’Muutu ihmiseksi, joka olet. Maalla-lehtijälkimodernin työntekijän ja paikan kuvaajana.” Alue ja ympäristö 39 (2): 39-52.

Ikonen, H-M. 2012.’Maaseudun naisyrittäjäksi tuleminen - esimerkki yrittäjäidentiteetin rakentumisesta." Maaseudun Uusi Aika 20 (1): 5-19.

Jakonen, M., J. Peltokoski, and A. Virtanen. 2006. Uuden työn sanakirja. Helsinki: Tutkijaliitto.

Jokinen, E. 2010. “Kodin, työn ja talouden uusi järjestys.” Janus 18 (1): 48-60.

Jokinen, E., J. Könönen, J. Venäläinen, and J. Vähämäki, eds. 2011. ”Yrittäkää edes!” Prekarisaatio Pohjois-Karjalassa. Helsinki: Tutkijaliitto.

Keith, M., and S. Pile. 1993. Place and the Politics of Identity. London: Routledge.

Komulainen, K., P. Naskali, M. Korhonen, and S. Keskitalo-Foley. 2011. "Internal Entrepreneurship - a Trojan Horse of the Neoliberal Governance of Education? 
Finnish Pre- and In-Service Teachers' Implementation of and Resistance Towards Entrepreneurship Education.” Journal for Critical Education Policy Studies 9 (1): $342-374$.

Lahikainen, L., and K. Mäkinen. 2012. "Luokka erona ja antagonismina." Kulttuurintutkimus 29 (1): 3-18.

Mäkinen, K. 2012. Becoming Valuable Selves. Self-Promotion, Gender and Individuality in Late Capitalism. Tampere: Tampere University Press.

Massey, D. 1994. Space, Place and Gender. Cambridge: Polity Press.

McDowell, L. 1999. Gender, Identity and Place. Cambridge: Polity Press.

McDowell, L. 2009. Working Bodies. Malden: Wiley-Blackwell.

Meriläinen, H. 2011. "Palkkatyöyhteiskunnan vaihtoehdot." In "Yrittäkää edes!" Prekarisaatio Pohjois-Karjalassa, edited by E. Jokinen, J. Könönen, J. Venäläinen, and J. Vähämäki, 143-162. Helsinki: Tutkijaliitto.

Miller, P., and N. Rose. 2008. Governing the Present. Cambridge: Polity Press.

Morris, J. 2012. "Unruly Entrepreneurs: Russian Worker Responses to Insecure Formal Employment." Global Labour Journal 3 (2): 217-236.

NíLaoire, C. 2001. “A Matter of Life and Death?: Men, Masculinities and Staying 'Behind' in Rural Ireland.” Sociologia Ruralis 41 (2): 220-236.

Obgor, J. 2000. Mythicizing and Reification in Entrepreneurial Discourse: Ideologycritique of Entrepreneurial Studies. Journal of Management Studies 37 (5): 605635. 
Palkkatyöläinen. 2011.“Teema: itsensä työllistäjät.” http://www.palkkatyolainen.fi/pt2011/pt-01-2011/pt-150211-t9.html

Peltokoski, J. 2012. Luokka luokkaa vastaan. Niin \& näin 19 (1): 98-101.

Pongratz, H. J., and G. Voss. 2003. "From Employee to 'Entreployee'. Towards a 'SelfEntrepreneurial' Work Force?" Concepts and Transformation 8 (3): 239-254.

Relph, E. 1986. Place and Placelessness. London: Pion.

Ricoeur, P. 1991. "Narrative Identity." In On Paul Ricoeur. Narrative and Interpretation, edited by D. Wood, 188-200. New York: Routledge.

Riessman, C.K. 2001. "Analysis of Personal Narratives.” In Handbook of Interview Research: Context and Method, edited by J. Gubrium, and J. Holstein, 695-710. Thousand Oaks, CA: Sage.

Rose, N. 1992. "Governing the Enterprising Self.” In The Values of the Enterprise Culture: The Moral Debate, edited by P. Heelas, and P. Morris, 141-163. London: Routledge.

Ross, A. 2009. Nice Work if You Can Get It: Life and Labor in Precarious Times. New York: New York University Press.

Rural Development Programme for Mainland Finland 2007-2013. 2007. http://www.maaseutu.fi/attachments/6BQQITgHU/Rural_Development_for_Main land_Finland_051012_EN.pdf

Sennett, R. 2006. The Culture of the New Capitalism. New Haven: Yale University Press. 
Skeggs, B. 1997. Formations of Class and Gender: Becoming Respectable. London: Sage.

Skeggs, B. 2004. Class, Self, Culture. London: Routledge.

Standing, G. 2011. The Precariat: The New Dangerous Class. London: BloomsburyAcademic.

TEM (Työ- ja elinkeinoministeriö). 2010. "MoniNainen ja uudistuva naisyrittäjyys." http://www.tem.fi/files/25810/TEM_4_2010.pdf

Tolonen, T. 2005. "Locality and Gendered Capital of Working-Class Youth.” Young 13 (4): 343-361.

Tuan, Y. 1977. Space and Place: The Perspective of Experience. Minneapolis: University of Minnesota Press.

Uimonen, M. 2008. ’Monikulttuurinen parisuhde ja suomalaisen julkisuuden sukupuolittuneet luokkakuvat.” In Yhteiskuntaluokka ja sukupuoli, edited by T. Tolonen, 122-145. Tampere: Vastapaino.

Varis, S. 2005. Pitkäaikaistyöttömänä maaseudulla. Joensuu: Joensuun yliopisto.

Veijola, S., and E. Jokinen. 2008. "Towads a Hostessing Society? Mobile Arrangements of Gender and Labour.” NORA 16 (3): 166-181.

Vähämäki, J. 2009. Itsen alistus. Työ, tuotanto ja valta tietokykykapitalismissa. Helsinki: Like. 
Watson, T. 2009. "Entrepreneurial Action, Identity Work and the Use of Multiple Discursive Resources. The Case of Rapidly Changing Family Business." International Small Business Journal 27 (3): 251-274. 